\title{
Investigation and Research on the Current Situation of Special Sports Development for Mentally Retarded Students in Sichuan Province
}

\author{
$\mathrm{Ye} \mathrm{He}$ \\ Physical Culture Institute \\ Leshan Normal University \\ Leshan, China
}

\begin{abstract}
Physical education is an important part of special education. The main purpose of physical education in special schools is to compensate and recover the defects. This paper uses questionnaires, interviews, on-site inspections, literature and other methods to investigate the development of sports in 14 special schools in Sichuan Province. From the four aspects of school construction, teacher strength, student attitude and teaching activities, it is found that students from special schools, especially those in the Department of Intellectual Development, are very fond of physical education classes and are eager to participate in more physical exercise. Their enthusiasm and desire exceed those of other departments; the physical education faculty in the Department of Mentally Retarded Students is weak, and the venues and equipment for non-physical education majors are scarce. In addition, there is also a fact that equipment is sufficient but no professional physical education educators to guide students to exercise and lack of funds. All of these situations are the main objective reasons hindering the development of school physical education.
\end{abstract}

Keywords-mentally retarded students; special education; research report

\section{INTRODUCTION}

Special sports play an important role in special education. Physical exercise is the best way to make special students happy, improve health, ameliorate movement obstacles, strengthen communication, enhance friendship and promote unity. Sports competition is an ideological education for special students, the best favorable choice to cultivate their spirits of loving collectives and create a cohesive force. The Provisional Regulations for Special Education Schools promulgated by the Ministry of Education require special education schools to help the disabled students to "master the basic methods of physical exercise, have good personal hygiene habits, and improve physical quality and health level......initially have a grasp of the basic method of compensating physical and mental defects so that the physical and mental defects can be recovered to a certain extent ". It can be seen that defect compensation is an important part of the training objectives of special education schools. Compensation for physical and mental defects of disabled students through physical education is a special mission entrusted to school physical education by special education. All kinds of special children can reflect the performance of motor retardation. Therefore, there are many theories and practices in special sports that can be used for reference in motor rehabilitation. Only by combining specia sports with motor rehabilitation can the role of "therapeutic education" be given full play.

Through the investigation, analysis and suggestions on the "special sports" of 13 special education schools in the province, the concept of action rehabilitation education is integrated into special physical education, which provides reference and suggestions for deepening the reform and development of special physical education.

\section{RESEARCH OBJECT AND METHOD}

\section{A. Research Object}

The research targeted at the teachers and students of 13 special schools in the province. The survey was conducted from February 2014 to December 2014.

\section{B. Research Method}

1) Liturature study: Through the search of Wanfang Data, CNKI, Academic Google and other libraries, the author has earnestly and thoroughly studied the relevant literature of special children's physical exercise, physical rehabilitation, motor rehabilitation, and so on, to understand the current situation of special sports research at home and abroad, and to make theoretical preparations for the investigation of this article.

2) Interviewing method: The author interviewed teachers or leaders of 13 special schools in Sichuan province through field investigation and telephone interview to understand the current situation of special sports in special schools 


\section{RESULTS AND ANALYSIS}

\section{A. Investigation on the Construction of 13 Special Education} Schools in Sichuan Province

TABLE I. General Situation Statistics of the Respondents

\begin{tabular}{|c|c|c|c|c|}
\hline Special School Name & $\begin{array}{l}\text { overing Area } \\
\text { (Mu) }\end{array}$ & $\begin{array}{l}\text { Total Number } \\
\text { of Students }\end{array}$ & $\begin{array}{l}\text { Total Number } \\
\text { of Teachers }\end{array}$ & Department \\
\hline Leshan Special Education School & 23.01 & 289 & 40 & $\begin{array}{l}\text { Department of Blindness, Department of Deaf Students, } \\
\text { Department of Intellectual Development }\end{array}$ \\
\hline Chengdu Special Education School & 22.5 & 420 & 103 & $\begin{array}{l}\text { Department of Blindness, Department of Deaf Students, } \\
\text { Department of Intellectual Development }\end{array}$ \\
\hline $\begin{array}{l}\text { Chenghua District Special Education } \\
\text { School in Chengdu }\end{array}$ & ion 13 & 51 & 14 & $\begin{array}{l}\text { Etiquette Education Class, Intellectual Education Class, } \\
\text { Energy Education Class and Talent Education Class }\end{array}$ \\
\hline $\begin{array}{l}\text { Longquanyi District Special } \\
\text { Education School in Chengdu }\end{array}$ & 3.4 & 20 & 7 & Department of Intellectual Development \\
\hline $\begin{array}{l}\text { Dujiangyan Special Education } \\
\text { School }\end{array}$ & 13.7 & 170 & 38 & Department of Deaf Students, Department of Intellectual Development \\
\hline $\begin{array}{l}\text { Naxi District Special Education } \\
\text { School in Luzhou }\end{array}$ & 6.20 & 98 & 14 & $\begin{array}{l}\text { Department of Blindness, Department of Deaf Students, } \\
\text { Department of Intellectual Development }\end{array}$ \\
\hline Xuyong Special Education School & 5.34 & 162 & 29 & Class for the Blind, Class for the Deaf, Class for Orphan \\
\hline Gulin Special Education School & 4.36 & 81 & 25 & Department of Intellectual Development, Department of the Deaf \\
\hline Yibin Special Education School & 9.6 & 128 & 45 & Department of the Blind, Department of the Deaf \\
\hline Xingwen Special Education School & 4.89 & 27 & 8 & Department of the Deaf \\
\hline $\begin{array}{l}\text { Chuanshan District Special Educatio } \\
\text { School in Suining }\end{array}$ & tion 10.5 & 156 & 47 & Department of the Deaf, Department of Intellectual Development \\
\hline Dazhou Special Education School & 2.5 & 88 & 18 & Class for the Deaf \\
\hline
\end{tabular}

From "Table I", it can be seen that the average area of 13 special education schools is about $9.16 \mathrm{mu}$; the total number of students is quite different; the number of teachers cannot meet the needs of students with the ratio of teachers to students of only 0.2 . From the above departments, there is a fact that in addition to the common deaf and blind students in special schools, the number of students in the Department of Intellectual Development has developed rapidly. The Department of Intellectual development includes children with affective disorders, autism, cerebral palsy, hyperactivity disorder, learning disabilities, multiple disorders and motor retardation. With the all-round development of our country, the number of mentally retarded students increases gradually, while the number of deaf-mute children decreases sharply. Through interviews, the author understands that the premise of enrollment in special education schools is that children must be able to walk, which makes many children with cerebral palsy who have better understanding lose the opportunity to enjoy equal education because they cannot walk. Another important factor affecting the admission of special children to school is the parents ,dilemma: if these children are sent to study, they will not have time for rehabilitation treatment; if they are sent for rehabilitation treatment, they will not have time for school. The reason why this situation exists lies in that both general education schools and special education schools lack teachers with rehabilitation skills. Although the concept of "combining medical education with teaching" has been put forward, it has not been implemented in the special schools surveyed, and the actual operation is pretty difficult. In the interview, the author also learned that only $35.9 \%$ of the 13 special education schools have small track and field with 100-200M runway; $30.77 \%$ have basketball courts (1-2); and $13.3 \%$ have simple table tennis tables. School sports venues and equipment are scarce in these schools. 


\section{B. Survey of the Faculty of 13 Special Education Schools}

TABle II. The Status Quo of InVestigation of Special Physical Education Teachers

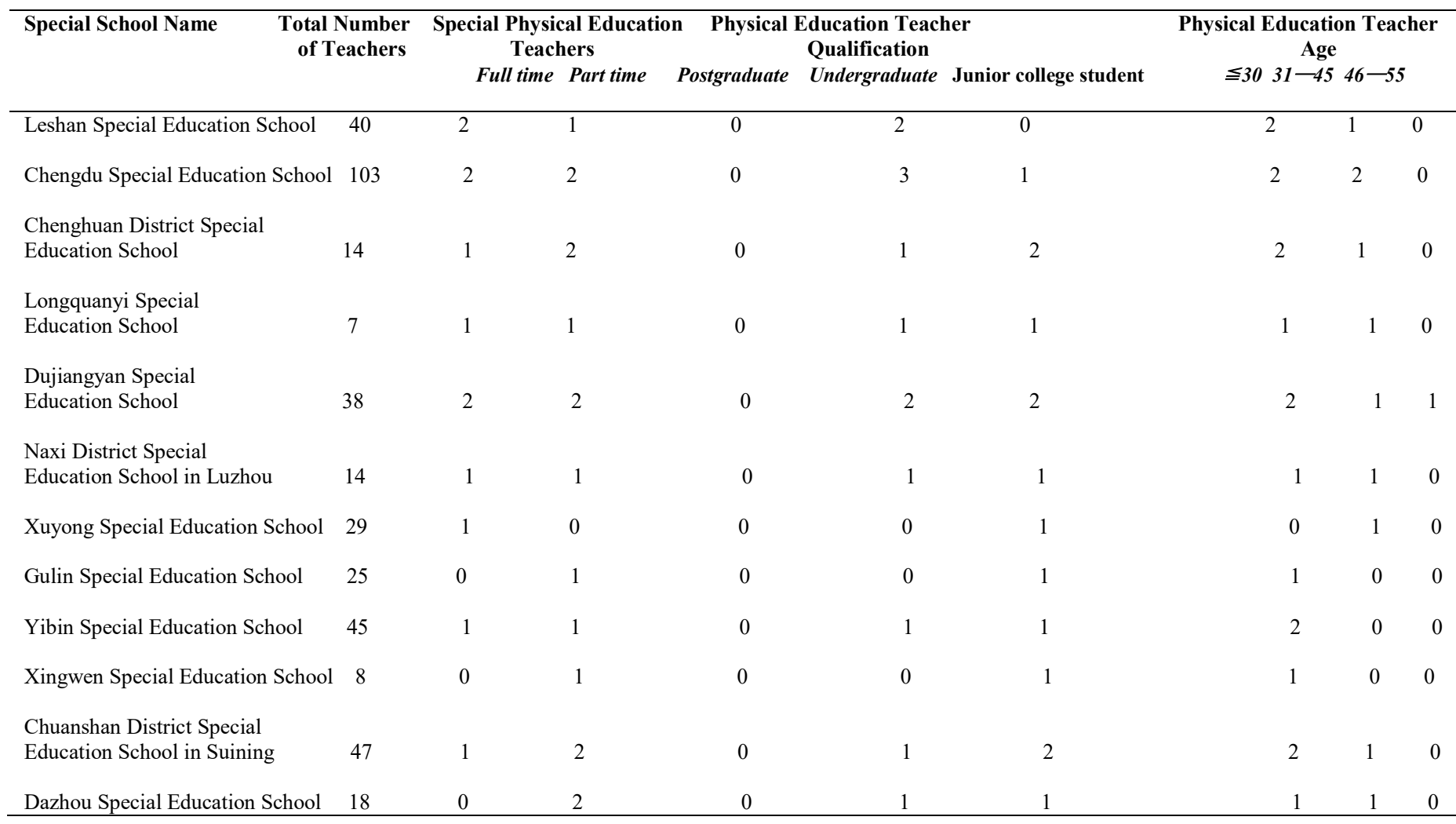

From "Table II", it can be seen that the number of fulltime PE teachers in 13 special education schools is very small, especially that Ministry of Intellectual Improvement lacks of full-time PE teachers; the educational background of $\mathrm{PE}$ teachers is low and most of them graduate from junior colleges with younger age and less teaching experience. These so-called full-time PE teachers are not professional special ones in fact without in-depth understanding of special children and characteristic expression teaching process. At the same time, $26.96 \%$ of PE teachers are non-sports majors. There are no full-time PE teachers in the Department of Intellectual Improvement of special education schools, and the phenomenon of being part-time is the majority. These part-time ones tend to serve as head teacher or lectures of other classes. During the interview, it was found that there are very few professional sports teachers who have researched or published relevant papers. The weak teachers have affected the quality, development and improvement of special sports in special education schools to a certain extent.Attitudes of Students in Special Schools Towards Physical Education

TABLE III. QUESTIONNAIRE ON THE ATTITUDES OF STUDENTS IN SPECIAL SCHOOLS TOWARDS PHYSICAL EDUCATION

\begin{tabular}{lllc}
\hline Attitude & Like & Quite Like & Dislike \\
\hline Number of students & 1285 & 270 & 135 \\
Percentage & 76.04 & 16 & 7.98 \\
\hline
\end{tabular}

It can be seen from "Table III" that $76.04 \%$ of students like physical education. However, it is not because of the physical education itself but because students feel that they can play outside instead of staying in the classroom in physical education. This shows that students in special education schools do not have a correct understanding of physical education, but also reflects that physical education teaching lacks professionalism from the side. $7.89 \%$ of students dislike attending physical education, because these students have obvious dysplasia and cannot participate in sports activities like other students, which makes them feel excluded. This also shows that physical education teachers fail to take into account the special needs of these students when conducting physical education teaching.

\section{The Developing Forms of Special Physical Education in Special Education Schools}

TABLE IV. QUESTIONNAIRE ON DEVELOPING Forms of SPECIAL PHYSICAL EDUCATION

\begin{tabular}{|l|l|l|l|l|l|}
\hline \multicolumn{2}{|c|}{ School Sports Meeting } & \multicolumn{2}{c|}{$\begin{array}{c}\text { Municipal Sports } \\
\text { Meeting }\end{array}$} & \multicolumn{2}{c|}{$\begin{array}{c}\text { Extracurricular } \\
\text { Activities }\end{array}$} \\
\hline $\begin{array}{l}\text { Held every } \\
\text { year }\end{array}$ & $\begin{array}{l}\text { Not } \\
\text { held }\end{array}$ & Held & $\begin{array}{l}\text { Not } \\
\text { held }\end{array}$ & Organized & $\begin{array}{l}\text { Not } \\
\text { organized }\end{array}$ \\
\hline $61.5 \%$ & $38.2 \%$ & None & & $94.87 \%$ & $5.13 \%$ \\
\hline
\end{tabular}

As can be seen from "Table IV", $61.5 \%$ of special schools in the province hold at least one school-level sports 
meeting every year, and $94.87 \%$ of special schools organize extracurricular activities every day. In extracurricular activities, schools only provide some equipment or students prepare their own equipment and participate in activities at their will. Teachers are less involved, and the weak atmosphere of students and teachers ${ }^{\text {ee }}$ participation in fitness causes that students lack help and protection. Especially, such phenomenon in the intelligence training department of special education schools is more obvious, which also affects the construction of the campus sports culture atmosphere to a certain extent.

\section{Investigation on the Contents of Physical Education Teaching in Special Education Schools}

TABLE V. QUESTIONNAIRE ON THE CONTENTS OF PHYSICAL EDUCATION TEACHING IN SPECIAL EDUCATION SCHOOLS

\begin{tabular}{|l|l|l|l|c|}
\hline $\begin{array}{l}\text { Physical } \\
\text { Education } \\
\text { Teaching Contents }\end{array}$ & $\begin{array}{l}\text { Track and } \\
\text { Field } \\
\text { (Running, } \\
\text { Throwing) }\end{array}$ & $\begin{array}{l}\text { Ball Games } \\
\text { (Basketball, } \\
\text { Badminton) }\end{array}$ & $\begin{array}{l}\text { Gymna } \\
\text { stics }\end{array}$ & Game \\
\hline Number of students & 10 & 8 & 5 & 7 \\
\hline
\end{tabular}

From "Table V", we can see that physical education teachers in special education schools mostly choose track and field and ball games as their teaching contents, which are similar to the teaching contents for ordinary primary and secondary school students. However, these activities do not have the effect of defect compensation and rehabilitation for special children, and are difficult for them to complete to a certain extent. The contents and forms of physical education teaching lack particularity and tend to be general.

Special children are different in sports activities because of their particularity. For example, adaptive function training for students with visual impairment is mainly concentrated on touch, hearing, vision, balance, proprioception, orientation, body imagination, spatial consciousness and so on. These training can be embodied in mobility orientation, balance beam and other activities in sports activities. Students of intelligence training department should design and select some sports activities suitable for them based on the physical quality and intelligence difference of each stage, so as to achieve the consistency of thinking, hearing, vision and movement. Schools should cultivate students ${ }^{\text {ee }}$ attention and reaction ability, develop their sensitivity and coordination towards movements, and comprehensively exercise their body. The horizontal bar exercises for upper limbs, finger exercises for fine movements, and core strength training methods for core areas can be used. Moreover, in different age groups of children with special needs, physical activities are also increasing and have its own emphasis. In the above questionnaire, there is no representation.

\section{CONCLUSION AND SUGGESTIONS}

\section{A. Conclusion}

1. Judging from the 13 special education schools surveyed, their weak faculty, insufficient full-time teachers, and teachers with low education level, weak research ability, insufficient understanding of leadership thought cause some problems. The young and middle-aged teachers occupy a large part of faculty, but their degree of specialization is low and they lack relevant experience on the physical education of special education school, added with less related training and insufficient input of physical education teachers on physical education, these problems affect the development of physical education.

2. Physical education teachers do not fully understand the purpose and content of special physical education. There are too many general teaching contents of physical education in special education schools, and the content of defects compensation and rehabilitation is relatively lacking; the learning methods of physical education of students in special education schools are still traditional learning methods. The single method of learning and the lack of interest in physical education can not attract the majority of students to have an interest in physical education and students ${ }^{\text {ee }}$ sports awareness is not strong.

3. The teaching facilities and equipment of physical education are few and old, and their "common" and "competitive" characteristics are not conducive to helping the compensation and rehabilitation for special children es defects. The school's physical education materials not only fail to meet the requirements of special schools, but also not to meet the requirements of ordinary schools.

4. Insufficient implementation of sports competitions, few municipal sports meeting and large-scale individual competitions, failing to connecting with the International Games for the Disabled, single event of group activities, events that lack guidance, protection and help and weak atmosphere for teachers and students fitness limits the development of physical education.

\section{B. Suggestions}

1. We should improve the concept of the running of special education schools, establish the development concept of "health first", focus on all-round development, and correctly understand the compensation effect of special physical rehabilitation on students ${ }^{\text {ee }}$ defects.

2. We should strengthen the training of teachers. For example, School of Physical Education of Leshan Normal University has offered courses for special physical education in the major of physical education to train full-time special physical education teachers with "rehabilitation skills".

3. Special education schools and competent departments should attach importance to the construction of school sports grounds and equipment, increase fund investment in sports, and improve the conditions of existing grounds and equipment, to provide a better platform for special school students to participate in sports, so that they can achieve better results in the Special Olympics and National Games of Disabled Persons People's Republic of China, build up confidence and enhance the quality of life.

4. We should increase rehabilitation equipment, train rehabilitation teachers, and develop the education concept of rehabilitation so that special children can receive better rehabilitation training while enjoying equal education. 


\section{REFERENCES}

[1] Sun Yanming, Chang Chunfang. Investigation and Research on the Current Situation of Physical Education in Special Education Schools in Bijie Experimental Area under the Background of "Sunshine Sports" [J]. Journal of Chifeng University (Natural Science Edition), 2014, (4): 130-132. (in Chinese)

[2] Sun Mei. Analysis on the Present Situation and Countermeasures of Physical Education in Special Education Schools in Xiean [J]. Shanxi Education (Higher education), 2014, (7): 64-65. (in Chinese)

[3] Zhang Simin. Investigation and Analysis of the Present Situation of Physical Education Teachers in Special Education Schools in Taiyuan City [D]. Taiyuan University of Technology, 2013. (in Chinese)

[4] Wang Wei. Investigation and Analysis on the Present Situation of Sunshine Sports in Special Education Schools of Liaoning Province [D]. (Liaoning Normal University, 2011. (in Chinese)

[5] Zhou Kun, Sang Yuan. Research on the Present Situation and Development of Extracurricular Sports in Special Education Schools - A Case Study of Anhui Province [J]. Journal of Chengdu Sport University, 2011, 37 (8): 64-67. (in Chinese)

[6] Gou Fengyun, Xiaomei, Tong Changjiang, et al. Investigation and Research on the Current Situation of Special Physical Education in Colleges and Universities in Inner Mongolia [J]. Journal of Hulunbeier Universities, 2013, 21 (3): 100-103. (in Chinese)

[7] Bao Ying, Shao Jingyu. Research on Situation and Countermeasures of Physical Education in Special Schools in Dalian [J]. Journal of Dalian University, 2014, (2): 138-142. (in Chinese). 